\title{
Study on Spatial Structure Dynamic Evolution of Tourism Economic Zone along Wuhan-Guangzhou HSR
}

\author{
Chun Liu'1,2 \\ ${ }^{1}$ Department of Management, Wuhan Technology and Business University, Wuhan, China \\ ${ }^{2}$ Hubei Business Service Development Research Center, Wuhan, China \\ Email: 317194469@qq.com
}

How to cite this paper: Liu, C. (2017) Study on Spatial Structure Dynamic Evolution of Tourism Economic Zone along Wuhan-Guangzhou HSR. Open Access Library Journal, 4: e4045. https://doi.org/10.4236/oalib.1104045

Received: October 20, 2017

Accepted: December 3, 2017

Published: December 6, 2017

Copyright (c) 2017 by author and Open Access Library Inc.

This work is licensed under the Creative Commons Attribution International License (CC BY 4.0).

http://creativecommons.org/licenses/by/4.0/ (c) (i) Open Access

\begin{abstract}
Wuhan-Guangzhou HSR is a passenger line, communication with Wuhan Urban Agglomeration, Changsha-Zhuzhou-Xiangtan Urban Agglomeration and the Pearl River Delta Urban Agglomeration. Wuhan-Guangzhou HSR achieves a bus-based operation, shortens the distance between cities, conducive to economic development, regional tourism. Applying Point Axis theory and Spatial Structure theory, this paper analyzes and contrasts regional economy and society, analyzing the dynamic change of regional tourism economy along Wuhan-Guangzhou HSR with its operation for the past five years, revealing high-speed transportation on the impact of regional tourism space, proposes that Tourism Economic Zone along Wuhan-Guangzhou HSR is divided into core tourism economic zone, compact tourism economic zone and radiant tourism economic zone, and makes recommendations, promoting regional tourism economy healthy and rapid development.
\end{abstract}

\section{Subject Areas}

Economic System, Public Economics

\section{Keywords}

Wuhan-Guangzhou HSR, Tourism Economic Zone, Spatial Structure,

Dynamic Evolution

\section{Introduction}

After 5 years of operation, Wuhan-Guangzhou HSR fully implements the operation of High Frequency and Public Transport, connecting Wuhan Urban Ag- 
glomeration, Changsha-Zhuzhou-Xiangtan Urban Agglomeration and the Pearl River Delta Urban Agglomeration into an organic whole, achieving cross-regional Urban Integration traffic. Wuhan-Guangzhou HSR shortens the spatial perception distance between cities along the railway, speeds up the cooperative process of regional tourism, and promotes the integration of regional tourism resources.

The factors affecting the formation of regional tourism space include five aspects: tourist attraction, traffic conditions, accommodation, infrastructure and other service facilities [1]. Among them, the convenient transport mode is the precondition for the formation of large-scale regional tourism economic space. High-speed railway promotes the formation of Tourism Economic Zone along Wuhan-Guangzhou HSR, which is important to achieve the complementation of inter-provincial tourism resources in the Pan-PRD region, to promote the tourism economic cooperation between Hubei, Hunan, Guangdong provinces, and peripheral regions, to optimize and integrate regional tourism industry. By Wuhan-Guangzhou HSR, the Pearl River Delta Urban Agglomeration expands the hinterland, Hubei and Hunan provinces open the window facing to the forefront of reform and opening. The resultant force of regional tourism economic development will be more powerful.

Huang Ai-lian (2011) [2], Xiao Yan-fei (2013) [3], Wang De-gen (2015) [4] build a double logarithm model, use the new economic geography model, the grey prediction model, the social survey questionnaire, GIS and social network analysis method, to discuss the influence of Wuhan-Guangzhou HSR and Beijing-Shanghai HSR on the development of tourism and producer services industry in their neighboring areas, put forward the contribution of the diffusion and agglomeration effects of High-speed railway on the regional tourism and service industry. Li Lin (2011) [5], Yang Xi (2014) [6], Mu Cheng-lin (2015) [7] conduct a quantitative research about the impact the high-speed railway exerted on $\mathrm{Hu}$ nan Province, Yangtze River Delta region on the basis of Accessibility evaluation method, Moran's I index analysis method, the shortest travel time modified gravity model, analyze the change of tourism traffic pattern along the high speed railway. Yin Ping (2012) [8], Wang De-gen (2013) [9], Yang Zhong-yuan (2013) [10], Guo Jian-ke (2016) [11] take Zhengzhou-Xi'an HSR, Wuhan-Guangzhou HSR, Harbin-Dalian HSR for example, establish Social network analysis model, Transportation superiority degree model, Accessibility model to analyze the spatial variation characteristics of regional tourism structure along High-speed railway, then discuss the impact of transportation on the regional tourism spatial structure variation.

From the qualitative and macro point of view, from the perspective of economics, the new geography perspective, most of these studies explore the impact of transportation on the regional tourism economy and put forward the countermeasures for the development of regional tourism economy in the era of High-speed railway. This paper constructs the index reflecting the social, economic and tourism development of tourism economic zone along High-speed 
railway, quantitatively analyzes Tourism Economic Zone along Wuhan-Guangzhou HSR by mathematical statistics method, dynamically explores the spatial structure of Tourism Economic Zone along Wuhan-Guangzhou HSR based on the statistical data of 2010-2016, and puts forward the suggestion on the development of Tourism Economic Zone along Wuhan-Guangzhou HSR.

\section{The Definition of Spatial Area of Tourism Economic Zone along Wuhan-Guangzhou HSR}

On the basis of John Friedman's Core-Periphery Theory about the interaction and diffusion of city space, the core area is a subsystem of social regional organizations, which can generate and attract a large number of innovations; the periphery area is another subsystem, which is interdependent with the core area, and its development direction mainly depends on the core area. The core area and the periphery area form a complete space system. According to the development situation of economic and society and tourism of the region along $\mathrm{Wu}$ han-Guangzhou HSR, the spatial structure of Tourism Economic Zone along Wuhan-Guangzhou HSR is divided into the Core Tourism Economic Zone, the Compact Tourism Economic Zone and the Radiant Tourism Economic Zone. By the use of MapInfo software, draw the schematic diagram of spatial structure of Tourism Economic Zone along Wuhan-Guangzhou HSR (Figure 1). The specific area coverage is defined as follows:

\subsection{Area Coverage Definition of the Core Tourism Economic Zone}

The core cities along Wuhan-Guangzhou HSR, accept substance flow, people flow and energy flow transfer of High-speed railway, the interaction between the cities is the strongest and the most extensive. The area coverage includes the cities along Wuhan-Guangzhou HSR, such as Wuhan, Changsha, Guangzhou, Xianning, Yueyang, Zhuzhou, Hengyang, Chenzhou, Shaoguan and Qingyuan (Figure 1).

\subsection{Area Coverage Definition of the Compact Tourism Economic Zone}

The Compact Tourism Economic Zone close contact with the core cities along Wuhan-Guangzhou HSR, accept economic and social elements radiation from the core cities along High-speed railway, is highly interactive and integrated with the Core Tourism Economic Zone dependent on the aggregation effect of the existing Urban Agglomeration, form a highly concentrated area of people flow, substance flow, capital flow and information flow. The node cities in the Compact Tourism Economic Zone have a considerable scale of development, strong economic and social relations with each other. The Compact Tourism Economic Zone covers Wuhan Urban Agglomeration, Changsha-Zhuzhou-Xiangtan Urban Agglomeration and the Pearl River Delta Urban Agglomeration in addition to the core cities along High-speed railway. The spatial scale includes Huanggang, 


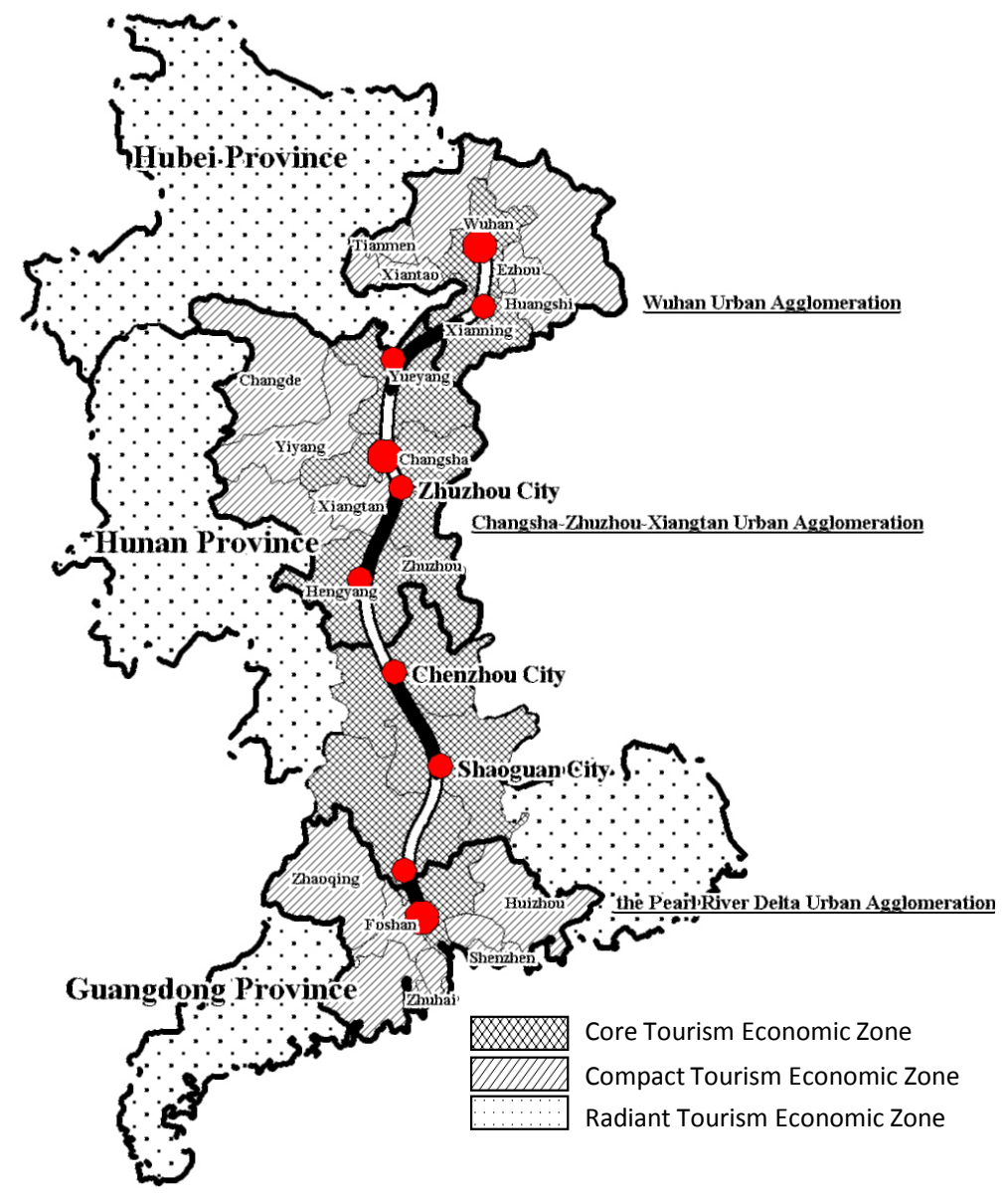

Figure 1. Schematic diagram of spatial structure of Tourism Economic Zone along Wuhan-Guangzhou HSR.

E’zhou, Huangshi, Xiaogan, Tianmen, Qianjiang and Xiantao in Wuhan Urban Agglomeration, Changde, Xiangtan, Yiyang and Loudi in Changsha-Zhuzhou-Xiangtan Urban Agglomeration, Shenzhen, Zhuhai, Foshan, Jiangmen, Dongguan, Zhongshan, Zhaoqing and Huizhou in the Pearl River Delta Urban Agglomeration (Figure 1).

\subsection{Area Coverage Definition of the Radiant Tourism Economic Zone}

From the tourism economic potential energy and spatial accessibility of the cities in the Core Tourism Economic Zone and the Compact Tourism Economic Zone, the Radiant Tourism Economic Zone takes Wuhan-Guangzhou HSR as tourism economic transmission axis, takes the cities of the Core Tourism Economic Zone as tourism economic growth pole, takes transport network of the Compact Tourism Economic Zone as tourism economic conduction carrier, tourism economy of which radiates remote areas in Hubei Province, Hunan province and Guangdong Province. The spatial scale covers the western Hubei Province of Hubei Province, the Xiangxi region of Hunan Province, the eastern and the western Guangdong Province (Figure 1). 


\section{Study on Spatial Structure Dynamic Evolution of Tourism Economic Zone along Wuhan-Guangzhou HSR}

\subsection{Economic-Social-Tourism Analysis of the Core Tourism Economic Zone}

According to statistical data from Hubei Statistical Yearbook (2010-2016), Hunan Statistical Yearbook (2010-2016), Guangdong Statistical Yearbook (2010-2016) and Chinese City Statistical Yearbook (2010-2016), collecting variables data such as Land Area, GDP, Residents Population, Per Capita GDP, Gross Industrial Output Value, Business Volume of Postal and Telecommunication Services, Urbanization rate. By means of mathematical statistics, quantitatively reflects the social economic development situation of the Core Tourism Economic Zone (such as Table 1).

The Core Tourism Economic Zone covers an area of $13.65 \times 10^{4} \mathrm{~km}^{2}$, which is 23.63\% of the total area of Hubei Province, Hunan province and Guangdong province. After 5 years operation, Wuhan-Guangzhou HSR narrow the distance between big cities, the attraction of towns and cities along Wuhan-Guangzhou HSR is also increasing, the economic and social changes have significantly taken place in the Core Tourism Economic Zone, agglomeration of which highlights

Table 1. The social economic development situation of the Core Tourism Economic Zone.

\begin{tabular}{|c|c|c|c|c|c|c|c|c|c|c|c|c|c|}
\hline & \multirow[t]{2}{*}{$\begin{array}{l}\text { Land area } \\
(\mathrm{sq} \cdot \mathrm{km})\end{array}$} & \multicolumn{2}{|c|}{$\begin{array}{c}\text { GDP } \\
(100 \text { million yuan })\end{array}$} & \multicolumn{2}{|c|}{$\begin{array}{c}\text { Residents } \\
\text { population } \\
(10,000 \text { persons })\end{array}$} & \multicolumn{2}{|c|}{$\begin{array}{l}\text { Per capita GDP } \\
\quad \text { (yuan) }\end{array}$} & \multicolumn{2}{|c|}{$\begin{array}{l}\text { Gross industrial } \\
\text { output value (100 } \\
\text { million yuan) }\end{array}$} & \multicolumn{2}{|c|}{$\begin{array}{l}\text { Business volume } \\
\text { of postal and } \\
\text { telecommunication } \\
\text { services } \\
\text { (100 million yuan) }\end{array}$} & \multicolumn{2}{|c|}{$\begin{array}{l}\text { Urbanization } \\
\text { rate }(\%)\end{array}$} \\
\hline & & 2009 & 2015 & 2009 & 2015 & 2009 & 2015 & 2009 & 2015 & 2009 & 2015 & 2009 & 2015 \\
\hline Wuhan & 8494 & 4620.18 & 10905.6 & 910.00 & 1060.77 & 51136 & 104132 & 5798.88 & 12862.95 & 293.82 & 356.71 & 59.45 & 79.41 \\
\hline Xianning & 9861 & 418.45 & 1030.07 & 252.00 & 250.70 & 16644 & 41234 & 443.14 & 1734.86 & 9.37 & 15.26 & 16.19 & 49.95 \\
\hline Yueyang & 15087 & 1272.15 & 2886.28 & 548.34 & 562.92 & 24542 & 51429 & 1997.41 & 4922.14 & 66.95 & 62.47 & 46.70 & 54.01 \\
\hline Changsha & 11816 & 3744.76 & 8510.13 & 651.59 & 743.18 & 56620 & 115443 & 3045.82 & 10565.20 & 207.36 & 251.80 & 62.63 & 74.38 \\
\hline Zhuzhou & 11248 & 1024.89 & 2335.11 & 382.80 & 400.05 & 27536 & 58661 & 1231.39 & 2547.55 & 62.09 & 60.41 & 50.30 & 62.10 \\
\hline Hengyang & 15299 & 1168.01 & 2601.58 & 739.80 & 733.75 & 17299 & 35538 & 1276.45 & 2075.57 & 72.01 & 66.54 & 43.15 & 49.20 \\
\hline Chenzhou & 19730 & 843.23 & 2012.07 & 473.86 & 473.02 & 19059 & 42682 & 913.31 & 3235.20 & 60.61 & 50.49 & 42.36 & 50.34 \\
\hline Shaoguan & 18463 & 578.75 & 1149.98 & 296.94 & 293.15 & 19546 & 39380 & 599.23 & 1221.78 & 67.51 & 45.17 & 47.29 & 54.29 \\
\hline Qingyuan & 19036 & 861.59 & 1277.86 & 382.71 & 383.45 & 22796 & 33392 & 2024.06 & 1680.13 & 85.06 & 61.24 & 34.93 & 49.07 \\
\hline Guangzhou & 7434 & 9138.21 & 18100.41 & 1033.45 & 1350.11 & 89082 & 136188 & 11376.76 & 18424.73 & 723.45 & 1092.94 & 82.53 & 85.53 \\
\hline Above total & 136468 & 23670.22 & 50809.09 & 5671.49 & 6251.1 & 41735.45 & 81280 & 28706.45 & 59270.11 & 1648.23 & 2063.03 & 54.40 & 66.77 \\
\hline $\begin{array}{l}\text { Total } \\
\text { statistics of } \\
\text { the three } \\
\text { provinces }\end{array}$ & 577500 & 65503.35 & 131264.95 & 22258.20 & 23553.53 & 29428.86 & 55730 & 97350.43 & 206690.29 & 5668.32 & 6263.87 & 52.67 & 60.72 \\
\hline $\begin{array}{c}\text { Percentage } \\
(\%)\end{array}$ & 23.63 & 36.14 & 38.71 & 25.48 & 26.54 & 141.82 & 145.85 & 29.49 & 28.68 & 29.08 & 32.94 & 103.28 & 109.96 \\
\hline
\end{tabular}


the role in the three provinces such as Hubei Province, Hunan province and Guangdong Province, the economic and social development indicators of the Core Tourism Economic Zone have shown rapid growth, especially GDP, resident population, per capita GDP, industrialization, informatization and urbanization have made a great development. During the 2009-2015 year study period, the development speed of the above indicators except industrial development were faster than that of the three provinces, and the leading development advantages become increasingly obvious. The share of industrial development in the three provinces showed a downward trend.

After 5 years operation of Wuhan-Guangzhou HSR, reception of Domestic Tourists in the Core Tourism Economic Zone increased from 197.8243 million person-times in 2009 to 602.2834 million person-times in 2015. The corresponding period, Earnings from Domestic Tourism increased from 199.551 billion yuan to 775.12 billion yuan, Foreign Exchange Earnings from International Tourism increased from 4.5012 billion USD to 8.150 billion USD. Domestic Tourists and Earnings from Domestic Tourism accounted for more than $40 \%$ of the three provinces such as Hubei Province, Hunan province and Guangdong Province, and grows significantly. The proportion of Foreign Exchange Earnings from International Tourism in the three provinces shows a trend of fluctuation (Table 2). From the above analysis, it can be concluded that tourism economy developed, transport network fast and convenient in the Core Tourism Economic Zone, especially the role of the railway. The Core Tourism Economic Zone has the advantages of funds, information, markets, etc. Wuhan-Guangzhou HSR operation and greatly enhance the strength of tourism economy core tourism economic zone. The operation of Wuhan-Guangzhou HSR has greatly improved the tourism economic strength of the Core Tourism Economic Zone.

Table 2. The tourism economic development situation of the Core Tourism Economic Zone (2009-2015).

\begin{tabular}{|c|c|c|c|c|c|c|}
\hline \multirow{2}{*}{ Year } & \multicolumn{2}{|c|}{ Domestic tourists ( 10,000 person-times $)$} & \multicolumn{2}{|c|}{$\begin{array}{l}\text { Earnings from domestic tourism } \\
\qquad(100 \text { million yuan })\end{array}$} & \multicolumn{2}{|c|}{$\begin{array}{l}\text { Foreign exchange earnings from } \\
\text { international tourism ( } 100 \text { million USD) }\end{array}$} \\
\hline & Value & $\begin{array}{l}\text { Percentage of the three } \\
\text { provinces (\%) }\end{array}$ & Value & $\begin{array}{l}\text { Percentage of the three } \\
\text { provinces }(\%)\end{array}$ & Value & $\begin{array}{l}\text { Percentage of the three } \\
\text { provinces (\%) }\end{array}$ \\
\hline 2009 & 19782.43 & 42.58 & 1995.51 & 45.28 & 45.012 & 40.15 \\
\hline 2010 & 25941.99 & 34.00 & 2649.85 & 46.18 & 59.651 & 42.54 \\
\hline 2011 & 31910.67 & 43.52 & 3652.39 & 48.17 & 63.322 & 39.86 \\
\hline 2012 & 37958.29 & 42.93 & 4501.49 & 47.20 & 66.748 & 37.60 \\
\hline 2013 & 44513.15 & 43.06 & 5456.19 & 48.53 & 68.602 & 37.45 \\
\hline 2014 & 50985.92 & 43.47 & 6284.96 & 46.37 & 70.54 & 36.91 \\
\hline 2015 & 60228.34 & 46.13 & 7750.12 & 48.92 & 81.50 & 39.92 \\
\hline
\end{tabular}




\subsection{Economic-Social-Tourism Analysis of the Compact Tourism Economic Zone}

From the social economic development situation of the Compact Tourism Economic Zone (Table 3), the Compact Tourism Economic Zone covers an area of $13.21 \times 10^{4} \mathrm{~km}^{2}$, which is $22.88 \%$ of the total area of Hubei Province, Hunan province and Guangdong province. By means of the transport network system in Wuhan Urban Agglomeration, Changsha-Zhuzhou-Xiangtan Urban Agglomeration and the Pearl River Delta Urban Agglomeration, relying on the huge socio-economic potential energy of the Core Tourism Economic Zone, the social

Table 3. The social economic development situation of the Compact Tourism Economic Zone.

\begin{tabular}{|c|c|c|c|c|c|c|c|c|c|c|c|c|c|}
\hline & \multirow[t]{2}{*}{$\begin{array}{c}\text { Land area } \\
(\mathrm{sq} . \mathrm{km})\end{array}$} & \multicolumn{2}{|c|}{$\begin{array}{c}\text { GDP } \\
\text { (100 million yuan) }\end{array}$} & \multicolumn{2}{|c|}{$\begin{array}{c}\text { Residents } \\
\text { population } \\
(10,000 \text { persons })\end{array}$} & \multicolumn{2}{|c|}{$\begin{array}{l}\text { Per capita GDP } \\
\text { (yuan) }\end{array}$} & \multicolumn{2}{|c|}{$\begin{array}{l}\text { Gross industrial } \\
\text { output value ( } 100 \\
\text { million yuan) }\end{array}$} & \multicolumn{2}{|c|}{$\begin{array}{l}\text { Business volume of } \\
\text { postal and } \\
\text { telecommunication } \\
\text { services ( } 100 \text { million } \\
\text { yuan) }\end{array}$} & \multicolumn{2}{|c|}{$\begin{array}{l}\text { Urbanization } \\
\text { rate (\%) }\end{array}$} \\
\hline & & 2009 & 2015 & 2009 & 2015 & 2009 & 2015 & 2009 & 2015 & 2009 & 2015 & 2009 & 2015 \\
\hline Huangshi & 4586 & 571.59 & 1228.11 & 243.00 & 245.80 & 23580 & 50053 & 860.99 & 2005.91 & 13.64 & 26.35 & 41.46 & 61.30 \\
\hline Ezhou & 1594 & 323.71 & 730.01 & 103.00 & 105.95 & 31308 & 68921 & 423.03 & 1286.41 & 22.51 & 10.21 & 26.26 & 64.30 \\
\hline Xiaogan & 8910 & 672.88 & 1457.20 & 468.00 & 487.80 & 14378 & 29924 & 688.14 & 2671.40 & 13.70 & 26.98 & 13.82 & 53.60 \\
\hline Huanggang & 17457 & 730.19 & 1589.24 & 669.00 & 629.10 & 10930 & 25321 & 570.96 & 1853.61 & 17.48 & 33.20 & 14.61 & 43.32 \\
\hline Xiantao & 2538 & 242.55 & 597.61 & 123.00 & 115.50 & 18759 & 51496 & 348.97 & 996.55 & 3.89 & 10.09 & 5.68 & 54.60 \\
\hline Tianmen & 2622 & 186.86 & 440.10 & 137.00 & 129.20 & 13653 & 34069 & 206.10 & 832.75 & 2.13 & 5.35 & 5.77 & 50.50 \\
\hline Qianjiang & 2004 & 234.01 & 557.57 & 94.00 & 95.80 & 24980 & 58201 & 365.15 & 1010.00 & 17.48 & 9.27 & 28.48 & 53.50 \\
\hline Xiangtan & 5006 & 739.38 & 1703.10 & 295.26 & 282.37 & 26608 & 60430 & 1086.27 & 2611 & 47.93 & 42.33 & 49.94 & 58.28 \\
\hline Changde & 18910 & 1239.23 & 2709.02 & 616.72 & 584.39 & 22496 & 46408 & 906.87 & 3054.30 & 70.47 & 65.79 & 38.30 & 47.59 \\
\hline Yiyang & 12320 & 591.62 & 1354.41 & 470.55 & 441.02 & 14071 & 30776 & 567.12 & 2020.80 & 47.50 & 45.36 & 41.50 & 46.39 \\
\hline Loudi & 8117 & 568.31 & 1291.67 & 420.50 & 387.18 & 14454 & 33444 & 752.73 & 1669.64 & 44.96 & 47.21 & 35.60 & 43.77 \\
\hline Shenzhen & 1992 & 8201.32 & 17502.86 & 891.23 & 1137.87 & 92772 & 157985 & 15416.24 & 25542.44 & 786.76 & 1069.43 & 100.00 & 100 \\
\hline Zhuhai & 1711 & 1038.66 & 2025.41 & 149.12 & 163.41 & 69889 & 124706 & 2405.04 & 3966.02 & 99.55 & 91.22 & 87.16 & 88.07 \\
\hline Foshan & 3798 & 4820.90 & 8003.92 & 599.68 & 743.06 & 80686 & 108299 & 11711.28 & 19544.95 & 297.19 & 282.87 & 92.36 & 94.94 \\
\hline Jiangmen & 9504 & 1340.88 & 2240.02 & 420.14 & 451.95 & 32139 & 49608 & 2933.26 & 3998.76 & 119.51 & 102.06 & 50.08 & 64.84 \\
\hline Dongguan & 2460 & 3763.91 & 6275.07 & 635.00 & 825.41 & 56601 & 75616 & 6071.11 & 12744.42 & 540.61 & 475.59 & 86.39 & 88.82 \\
\hline Zhongshan & 1800 & 1566.41 & 3010.03 & 251.74 & 320.96 & 62304 & 94030 & 4057.97 & 6345.28 & 176.89 & 156.64 & 86.34 & 88.12 \\
\hline Zhaoqing & 15464 & 862.00 & 1970.01 & 388.83 & 405.96 & 22415 & 48670 & 1179.01 & 4034.37 & 87.57 & 69.81 & 44.89 & 45.16 \\
\hline Huizhou & 11343 & 1414.70 & 3140.03 & 397.21 & 475.55 & 35819 & 66231 & 3005.14 & 7044.73 & 151.95 & 146.50 & 61.27 & 68.15 \\
\hline Above total & 132136 & 29109.11 & 57825.39 & 7372.98 & 8028.28 & 39480.79 & 72027 & 53555.38 & 103233.34 & 2561.72 & 2716.26 & 54.66 & 69.16 \\
\hline $\begin{array}{c}\text { Total statistics } \\
\text { of the three } \\
\text { provinces }\end{array}$ & 577500 & 65503.35 & 131264.95 & 22258.20 & 23553.53 & 29428.86 & 55730 & 97350.43 & 206690.29 & 5668.32 & 6263.87 & 52.67 & 60.72 \\
\hline $\begin{array}{c}\text { Percentage } \\
(\%)\end{array}$ & 22.88 & 44.44 & 44.05 & 33.12 & 34.09 & 134.16 & 129.24 & 55.01 & 49.95 & 45.19 & 43.36 & 103.78 & 113.90 \\
\hline
\end{tabular}


economic strength of the Compact Tourism Economic Zone can be greatly improved, especially urbanization and per capita GDP have been significantly improved. Urbanization increased from $54.66 \%$ in 2009 to $69.16 \%$ in 2015 , the per capita GDP increased from 39480.79 yuan to 72027 yuan, the growth rate of the above two indicators is higher than that of the three provinces such as Hubei Province, Hunan province and Guangdong Province. Wuhan-Guangzhou HSR plays an important role in promoting coordinated development between big cities and small and medium-sized cities.

It can be seen from Table 4, Domestic Tourists, Earnings from Domestic Tourism, Foreign Exchange Earnings from International Tourism in the Core Tourism Economic Zone increased respectively from 137.1631 million person-times, 140.397 billion yuan, 6.1262 billion USD in 2009 to 316.7226 million person-times, 410.383 billion yuan, 11.382 billion USD in 2015. The proportion of Domestic Tourists and Earnings from Domestic Tourism in the three provinces such as Hubei Province, Hunan province and Guangdong Province decreased obviously. The proportion of Foreign Exchange Earnings from International Tourism in the three provinces shows a growth trend. The Core Tourism Economic Zone is the main destinations for inbound tourism, Foreign Exchange Earnings from International Tourism accounted for more than $50 \%$ of the total of Hubei Province, Hunan province and Guangdong province.

The growth rate of the three tourism economic indicators such as Domestic tourists, Earnings from Domestic Tourism and Foreign Exchange Earnings from International Tourism in the Compact Tourism Economic Zone are lower than those of the Core Tourism Economic Zone. It is necessary to strengthen effective convergence between the transport of the three major urban agglomerations and the cities along Wuhan-Guangzhou HSR. Seen from Figure 1, there is a spatial discontinuity in the Compact Tourism Economic Zone. From the regional tourism economic development perspective, Changsha-Zhuzhou-Xiangtan Urban Agglomeration should plan Chenzhou into the development of Urban Agglomeration, the Pearl River Delta Urban Agglomeration should plan Shaoguan and

Table 4. The tourism economic development situation of the Compact Tourism Economic Zone (2009-2015).

\begin{tabular}{|c|c|c|c|c|c|c|}
\hline \multirow{2}{*}{ Year } & \multicolumn{2}{|c|}{ Domestic tourists $(10,000$ person-times $)$} & \multicolumn{2}{|c|}{$\begin{array}{l}\text { Earnings from domestic tourism } \\
\text { (100 million yuan })\end{array}$} & \multicolumn{2}{|c|}{$\begin{array}{l}\text { Foreign exchange earnings from } \\
\text { international tourism (100 million USD) }\end{array}$} \\
\hline & Value & $\begin{array}{l}\text { Percentage of the three } \\
\text { provinces }(\%)\end{array}$ & Value & $\begin{array}{l}\text { Percentage of the three } \\
\text { provinces (\%) }\end{array}$ & Value & $\begin{array}{c}\text { Percentage of the three } \\
\text { provinces (\%) }\end{array}$ \\
\hline 2009 & 13716.31 & 29.53 & 1403.97 & 31.86 & 61.262 & 54.64 \\
\hline 2010 & 16614.63 & 21.78 & 1727.60 & 30.11 & 72.871 & 51.97 \\
\hline 2011 & 19228.16 & 26.22 & 2139.21 & 28.22 & 85.743 & 53.97 \\
\hline 2012 & 22082.96 & 24.97 & 2571.27 & 26.96 & 99.771 & 56.20 \\
\hline 2013 & 25800.41 & 24.96 & 3042.13 & 27.06 & 107.231 & 58.54 \\
\hline 2014 & 27597.49 & 23.53 & 3506.16 & 25.87 & 109.64 & 57.36 \\
\hline 2015 & 31672.26 & 24.26 & 4103.83 & 25.90 & 113.82 & 55.75 \\
\hline
\end{tabular}


Qingyuan into the development of Urban Agglomeration. This can make tourism economic development of the Compact Tourism Economic Zone along Wuhan-Guangzhou HSR more efficient.

\subsection{Economic-Social-Tourism Analysis of the Radiant Tourism Economic Zone}

The Radiant Tourism Economic Zone covers an area of $30.89 \times 10^{4} \mathrm{~km}^{2}$, which is $53.49 \%$ of the total area of Hubei Province, Hunan province and Guangdong province. From Table 5, it can be seen that absolute values of GDP, Residents Population, Per Capita GDP, Gross Industrial Output Value, Business Volume of Postal and Telecommunication Services have increased in different degrees, but their proportion in the three provinces has declined. The absolute value of urbanization and its proportion in the three provinces have shown a slight downward trend. Gross Industrial Output Value is increasing rapidly, its proportion in the three provinces increased from $15.50 \%$ to $21.38 \%$ because of undertaking industries of the core cities along HSR and the coastal cities. The proportion of social and economic indicators except Gross Industrial Output Value in the Radiant Tourism Economic Zone is declining in the three provinces.

After 5 years aggregation and diffusion of Wuhan-Guangzhou HSR, the average annual growth rate of the three indicators such as Domestic Tourists, Earnings from Domestic Tourism, Foreign Exchange Earnings from International Tourism in the Radiant Tourism Economic Zone was 31.26\%, 26.47\% and $11.36 \%$ respectively, the increasing degree is obvious. The proportion of the above three indicators in the three provinces has increased to some extent, but remains low level, especially inbound tourism. We should further strengthen the access of the Radiant Tourism Economic Zone, speed up the pace of urbanization and enhance the construction of tourist reception facilities (Table 6).

\section{Conclusion}

Following the Point-Axis Development Theory, Tourism Economic Zone along Wuhan-Guangzhou HSR takes Wuhan-Guangzhou HSR as the development

Table 5. The social economic development situation of the Radiant Tourism Economic Zone.

\begin{tabular}{lcccc}
\hline & \multicolumn{2}{c}{2009} & 2015 \\
\cline { 2 - 4 } & Value & $\begin{array}{c}\text { Percentage of the three } \\
\text { provinces (\%) }\end{array}$ & $\begin{array}{c}\text { Value } \\
\text { Percentage of the three } \\
\text { provinces (\%) }\end{array}$ \\
\hline GDP (100 million yuan) & 12724 & 19.43 & 22630 & 17.24 \\
Residents population (10,000 persons) & 9214 & 41.39 & 9274.15 & 24402 \\
Per capita GDP (yuan) & 13810 & -15619 & 44187 & -31328 \\
Gross industrial output value (100 million yuan) & 15089 & 15.50 & 1484.6 & 21.38 \\
$\begin{array}{l}\text { Business volume of Postal and telecommunication } \\
\text { services (100 million yuan) }\end{array}$ & 1458 & 25.73 & 49.34 & 23.70 \\
Urbanization rate (\%) & 50.01 & -2.66 & -11.38 \\
\hline
\end{tabular}


Table 6. The tourism economic development situation of the Radiant Tourism Economic Zone (2009-2015).

\begin{tabular}{ccccccc}
\hline \multirow{2}{*}{ Year } & Domestic tourists (10,000 person-times) & $\begin{array}{c}\text { Earnings from domestic tourism } \\
(100 \text { million yuan })\end{array}$ & $\begin{array}{c}\text { Foreign exchange earnings from } \\
\text { international tourism (100 million USD) }\end{array}$ \\
\cline { 2 - 6 } & Value & $\begin{array}{c}\text { Percentage of the } \\
\text { three provinces }(\%)\end{array}$ & Value & $\begin{array}{c}\text { Percentage of the three } \\
\text { provinces (\%) }\end{array}$ & $\begin{array}{c}\text { Value } \\
\text { Percentage of the three } \\
\text { provinces (\%) }\end{array}$ \\
\hline 2009 & 12955.80 & 27.89 & 1007.14 & 22.86 & 5.836 & 5.21 \\
2010 & 33740.54 & 44.22 & 1360.13 & 23.71 & 7.687 & 5.48 \\
2011 & 22183.22 & 30.25 & 1789.91 & 23.61 & 9.801 & 6.17 \\
2012 & 28382.34 & 32.10 & 2464.11 & 25.84 & 11.019 & 6.21 \\
2013 & 33060.61 & 31.98 & 2743.68 & 24.41 & 7.336 & 4.00 \\
2014 & 38705.37 & 33.00 & 3763.78 & 27.77 & 10.959 & 8.83 \\
2015 & 38652.21 & 29.61 & 3988.67 & 25.18 & 5.73 \\
\hline
\end{tabular}

axis, and gradually becomes the agglomeration area of tourism economy and urban economy upgrading. Referring to benefit analysis of the tourism economy generated by the operation of Wuhan-Guangzhou HSR in the past 5 years, tourism economic benefits are obvious, the promotion of tourism economic strength is relatively large, interaction between cities is strengthened, the aggregation and diffusion of tourist flows are prominent in Tourism Economic Zone along Wuhan-Guangzhou HSR. On the basis of the regional development along Wuhan-Guangzhou HSR and quantitative analysis of the data, the spatial structure of Tourism Economic Zone along Wuhan-Guangzhou HSR can be divided into the Core Tourism Economic Zone, the Compact Tourism Economic Zone and the Radiant Tourism Economic Zone. Tourism Economic Zone along $\mathrm{Wu}$ han-Guangzhou HSR takes the cities along Wuhan-Guangzhou HSR as the core growth pole to drive tourism economic development in the Compact Tourism Economic Zone, to build tourism economic compact district, to further promote the tourism economic development of the radiation edge area, and to promote the tourism economic competitiveness of the Radiation Tourism Economic Zone.

\section{References}

[1] Pearce, D. (1995) Tourist Development: A Geographical Analysis. Longman Press, London, 1-25.

[2] Huang, A.-L. (2011) Effects of High Speed Railway on Regional Tourism Development: Case of High Speed Railway between Wuhan and Guangzhou. East China Economic Management, 25, 47-49.

[3] Xiao, Y.-F., Zhang, Q., Cao, X.-N., et al. (2013) The Impact of Wuhan-Guangzhou High-Speed Railway on the Development of Hunan Producer Services. Economic Geography, 33, 103-107.

[4] Wang, D.-G., Chen, T., Lu, L., et al. (2015) Mechanism and HSR Effect of Spatial Structure of Regional Tourist Flow: Case Study of Beijing-Shanghai HSR in China. Acta Geographical Sinica, 70, 214-233.

[5] Li, L., Zhang, J.-R., Duan, Y.-N., et al. (2011) Study on the Impacts of Accessibility 
along the Wuguang High Speed Railway in Hunan. Economic Research Guide, 12, 144-148.

[6] Yang, X. and Wang, Z.-F. (2014) Exploratory Analysis of Hunan Tourist Flow Agglomeration and Diffusion Based on Traffic Network. Areal Research and Development, 33, 96-100.

[7] Mu, C.-L., Lu, L., Huang, J.-F., et al. (2015) Research on Yangtze River Delta Tourist Traffic Pattern and Linkage under the High-Speed Rail Network. Economic Geography, 35, 193-202.

[8] Yin, P. (2012) High-Speed Railway (HSR) and Establishment of New Pattern of Regional Tourism: A Case Study of the High-speed Railway between Zhengzhou and Xi'an. Tourism Tribune, 27, 47-53.

[9] Wang, D.G. (2013) The Impact of Wuhan-Guangzhou HSR on Regional Tourism Spatial Pattern in Hubei Province. Geographical Research, 32, 1555-1564.

[10] Yang, Z.-Y. and Lu, S. (2013) The Impacts of Traffic Improvements on Spatial Structure of Regional Tourism: Case of Southern Anhui. Scientia Geographica Sinica, 33, 806-814.

[11] Guo, J.-K., Wang, S.-B., Li, B., et al. (2016) The Spatial Effect of Harbin-Dalian High-speed Rail to the Northeast City Tourism Economic Link. Scientia Geographica Sinica, 36, 521-529. 